\title{
Volný mandát člena parlamentu v ústavním vývoji Československa a České republiky
}

\author{
Jan Kudrna
}

Právnická fakulta, Univerzita Karlova

Kontaktni e-mail: kudrnaj@prf.cuni.cz

ORCID: 0000-0001-8009-4294

The Free Mandate of the Members of Parliament in the Constitutional Development of Czechoslovakia and the Czech Republic

\begin{abstract}
:
This article deals with the issue of the matter of the mandate of members of parliament in the constitutional history of Czechoslovakia and the Czech Republic. Namely the article is dedicated to the problem, whether and when in the years 1918-2020 the mandate of the members of parliament was free or imperative. The detailed description shows, that in Czechoslovakia strongly prevailed the imperative mandate, irrespective of character of the political regime. The pre-war Czechoslovak constitution adopted in 1920 expressly declared the mandate as a free one and members of parliament should use it regardless of any instructions or commands. Nonetheless very quickly, in 1923, through the decision of the Election Court, the first deputies were deprived of their functions as a sanction for leaving their party policy. Thus, even in the democratic regime the mandate was transformed into the imperative form. After the WWII, the political circumstances in Czechoslovakia changed and the regime turned into a totalitarian form under the hegemony of the communist party. In these circumstances the deputies should serve as servants of the voters, to follow their instructions and they could be recalled, if not fulfilling the will of the (working) people. Nonetheless the recall system based on the public meetings of the voters was not very practical and it could fulfil the estimations only when the communist party has the situation fully under its control. In some critical moments other tools for recall had to be adopted, as it happened in the year 1969, when the political situation after the Prague Spring suppression needed to be consolidated and the will of the voters was different of the will of the conservative communist leaders. The last recalls appeared after the Velvet Revolution when democracy was re-established in Czechoslovakia. Thus, the free parliamentary mandate existed hardly in 8 years from 75 years of existence of Czechoslovakia. The last 30 years of its existence in the constitution of the Czech Republic and political practice is still quite an uncommon period in the Czechoslovak constitutional tradition.
\end{abstract}


Keywords: Czech Republic; constitution; parliament; immunity; responsibility; mandate; resignation; speech; voting; proposals; expression; freedom; free mandate; imperative mandate

Klíčová slova: Česká republika; ústava; parlament; imunita; odpovědnost; mandát; rezignace; projev; hlasování; návrhy; vyjádření; svoboda; volný mandát; imperativní mandát; vázaný mandát

DOI: $10.14712 / 2464689 X .2021 .20$

Financování: Tento článek byl vypracován v rámci programu PROGRES Q04.

Ústava České republiky (dále jen také „Ústava“) vychází ve věci postavení členů parlamentu ze základního principu, kterým je princip volného mandátu. Její čl. 26 vylučuje vázanost poslance či senátora jakýmikoliv př́ikazy. Člen parlamentu je vázán pouze svým slibem, což podle čl. 23 odst. 3 Ústavy znamená ve vztahu k charakteru mandátu jednání v zájmu všeho lidu a v souladu se svědomím př́slušného člena parlamentu. Jinými slovy, člen parlamentu má jednat tak, jak je sám přesvědčen, že je v zájmu celku. Důsledkem uplatnění principu volného mandátu je potom mj. neodvolatelnost člena parlamentu jeho voliči nebo politickou stranou, kterou byl do parlamentu nominován. Volný mandát znamená neexistenci právního závazku mezi členy parlamentu a lidem, př́ipadně zprostř̌edkujícími subjekty. Nicméně, jak uvádí mj. V. Pavlíček, existence volného mandátu nevylučuje existenci závazku politického, který je zhodnocen v dalších volbách. ${ }^{1}$

Jak zmiňuje J. Syllová, koncepce volného mandátu se ve vývoji parlamentarismu objevila a prosazovala postupně. Přičemž, jak uvádí, významným mezníkem v tomto vývoji byla řeč E. Burkeho zvoleného do anglického parlamentu v roce 1774, v níž upozornil na skutečnost, že parlament není sborem zmocněnců a advokátů nejrůznějších zájmů, často místního charakteru, ale jedná se o poradní sbor celého národa, který má hledat obecné dobro, oproštěné od nejrůznějších místních předsudků. ${ }^{2}$

Koncepce volného mandátu významně posílila s nástupem myšlenky svrchovanosti lidu a v řadě zemí dále se zavedením volebního systému poměrného zastoupení, který oproti systému většinovému oslabil dříve zřetelnou vazbu člena parlamentu s konkrétním místem a voliči v něm žijícími. ${ }^{3}$

Na tomto místě je ale nutno upozornit, že poměrný volební systém znamenal na jedné straně oslabení vazby člena parlamentu na konkrétní voliče, ale na druhou stranu ho učinil závislejším na politické straně, protože až na výjimky je poměrný volební systém spojen s existencí nominujícího subjektu v podobě politické strany.

Stojí také za upozornění, že imperativní mandát je v obecném vnímání intuitivně snadněji pochopitelný než mandát volný. To může být důvod opakovaného diskutování této otázky i v dnešní době, přičemž některé politické strany opětovně předkládají návrh změny

PAVLÍČEK, V. - HŘEBEJK, J. Ústava a ústavní rád České republiky. 1. díl. Praha: Linde, 1998, s. 147.

2 SLÁDEČEK, V. - MIKULE, V. - SUCHÁNEK, R. - SYLLOVÁ, J. Ústava České republiky. Komentár. Praha: C. H. Beck, 2016, s. 293.

3 Tamtéž. 
čl. 26, respektive v návaznosti na něj čl. 25 Ústavy. Konkrétně se jedná o Komunistickou stranu Čech a Moravy. ${ }^{4} \mathrm{~S}$ podobným požadavkem, zatím nekonkretizovaným, vystupuje také předseda Strany prímé demokracie T. Okamura. ${ }^{5}$

Vrátíme-li se však k upozornění J. Syllové ohledně toho, že volný mandát se ve vývoji parlamentarismu prosazoval postupně, stojí za pozornost, jak tomu bylo v ústavních dějinách Československa a České republiky.

\section{Podstata mandátu člena parlamentu podle ústavní listiny z roku 1920 a její proměna}

K podstatě mandátu člena parlamentu se na ústavní úrovni výslovně poprvé vyjádřila ústavní listina z roku $1920 .{ }^{6}$ Její $§ 22$ odst. 1 stanovil, že poslanci a senátoři svůj mandát vykonávají osobně a nesmějí od nikoho přijímat žádné př́kazy. Slib člena parlamentu navíc zavazoval k tomu, že svůj mandát bude vykonávat „podle svého nejlepšího vědomí a svědomí“. Ze všeho výše uvedeného vyplývá, že ústavní listina z roku 1920 počítala $\mathrm{s}$ tím, že mandát členů parlamentu bude volný. V praxi se však poměrně záhy ukázalo něco jiného. Volný charakter mandátu člena parlamentu byl prolomen.

Stalo se tak prostřednictvím $\S 19$ ústavní listiny. Ten stanovil, že o platnosti voleb do obou komor parlamentu rozhoduje volební soud s tím, že podrobnosti stanoví zákon. Tímto zákonem byl zákon o volebním soudu, schválený téhož dne jako ústavní listina a publikovaný pod č. 125/1920 Sb. z. a n. Tento zákon ve svém $\S 8$ stanovil, že Volební soud rozhoduje kromě jiného také o ztrátě mandátu člena parlamentu, a to v prípadech vymezených v $\S 13$.

Takové prrípady podle zákona mohly nastat dva. Ke ztrátě mandátu mohlo v prvé řadě dojít tehdy, když poslanec či senátor ztratil volitelnost. Tento případ nevyvolával žádné kontroverze a ostatně ani nijak nesouvisel s otázkou charakteru mandátu, zda je volný či vázaný. Problematické bylo z tohoto hlediska ustanovení $§ 13$ písm. b) popisovaného zákona. Stanovilo totiž, že člen Národního shromáždění může být zbaven mandátu tehdy, když ,,přestal býti z důvodů nízkých nebo nečestných př́slušníkem strany, z jejíž kandidátní listiny byl zvolen“. Uvedené ustanovení totiž nepostihovalo jen př́pady dnes označované jako „přeběhlictví“. Umožnilo člena parlamentu zbavit mandátu také tehdy, když byl poslanec nebo senátor vyloučen ze své politické strany pro nerespektování jejího postoje nebo stanoviska $\mathrm{k}$ věci projednávané v parlamentu. Toto druhé ustanovení $§ 13$ zákona o volebním soudu vyvolávalo od počátku kontroverze a bylo předmětem široké kritiky, protože nakonec ve spojení se ,vstřícností“"Volebního soudu vůči vedení politických stran vedlo ke zbavování členů parlamentu jejich mandátů právě proto, že byli svou politickou

4 Jedná se o tisk Poslanecké sněmovny č. 146 z V. volebního období, dále o tisk Poslanecké sněmovny č. 795 z V. volebního období, potom o tisk Poslanecké sněmovny č. 640 z VI. volebního období, a konečně o tisk Poslanecké sněmovny č. 65 z VIII. volebního období. [online]. Dostupné na: http://www.psp.cz/sqw $/$ text/tiskt.sqw?O $=5 \& \mathrm{CT}=146 \& \mathrm{CT} 1=0 ; \mathrm{http}: / / \mathrm{www} . \mathrm{psp} . \mathrm{cz} / \mathrm{sqw} / \mathrm{text} / \mathrm{tiskt} . \mathrm{sqw} ? \mathrm{O}=5 \& \mathrm{CT}=795 \& \mathrm{CT} 1=0$; http://www.psp.cz/sqw/text/tiskt.sqw?O=6\&CT=640\&CT1=0; http://www.psp.cz/sqw/text/tiskt.sqw?O=8 $\& \mathrm{CT}=65 \& \mathrm{CT} 1=0$. [cit. 25. 08. 2020].

5 Viz např. internetové zpravodajství ze dne 18. 08. 2013. [online]. Dostupné na: https://zpravy.idnes.cz /odvolatelnost-politiku-podle-okamury-i-ve-svete-f6m-/domaci.aspx?c=A130716_123239_domaci_jw. [cit. 25. 08. 2020].

6 Publikovaná jako ústavní zákon č. 121/1920 Sb. z. a n. 
stranou označeni za „odpadlíky“. Tím se vliv na mandát poslanců a senátorů přesunul od voličů směrem ke stranickým sekretariátům.

První z významných př́ípadů rozhodovaných Volebním soudem, který založil celou rozhodovací linii tohoto soudu ve vztahu k uvedenému ustanovení $§ 13$ písm. b) zákona o volebním soudu, byl př́ipad poslance B. Vrbenského a jeho kolegů T. Bartoška, V. Draxla a L. Landové-Štýchové. Podstata věci spočívala v tom, že všichni čtyři jmenovaní odmítli na sklonku zimy roku 1923 hlasovat pro tehdy navržený zákon na ochranu republiky. V důsledku toho je ústřední výbor Československé strany socialistické, jejímiž byli členy, dne 8. března 1923 vyloučil ze strany a požádal je, aby rezignovali na své poslanecké mandáty. Když poslanci odmítli výzvě vyhovět, obrátila se Československá strana socialistická na Volební soud s žádostí, aby byli zbaveni svých mandátů podle ustanovení $§ 13$ písm. b) zákona o volebním soudu.

Československá strana socialistická svou žádost podložila několika skutečnostmi. V prvé řadě odkázala na existenci tzv. poslaneckých reverzů, které všichni jmenovaní podepsali. V nich se zavázali řídit organizačními i programovými zásadami strany, hlasovat v souladu s usneseními ústředního výboru strany a jejího poslaneckého klubu, a pro př́pad porušení svých závazků souhlasili na výzvu strany na svůj mandát rezignovat. Vedle toho Československá strana socialistická poukázala na řadu dalších př́ípadů, kdy jmenovaní poslanci porušili rozhodnutí stranických orgánů i mimo jednání parlamentu.

Volební soud v celé věci definitivně rozhodl 23. června 1923 a vyslovil názor, že člen parlamentu se může dobrovolně vzdát výhody, kterou mu poskytuje ustanovení $§ 13$ písm. b) zákona o volebním soudu, tedy možnosti opustit stranu, za niž kandidoval, bez hrozby ztráty mandátu, pokud se tak ovšem děje z příčin, které nejsou nízké a nečestné. Porušení dobrovolně podepsaného poslaneckého reverzu za takovou příčinu považoval. Ve vztahu k ustanovení § 22 ústavní listiny zakazujícímu členům Národního shromáždění přijímání příkazů od kohokoliv uvedl, že tento předpis ,zakazuje členu Národního shromáždění pouze přijímati př́íkazy co do vykonávání mandátu, nezakazuje mu však, aby mandátu se vzdal, at' už vůbec a kdykoliv, nebo za určitých podmínek, jež by snad v budoucnu nastaly“. 7 Toto rozhodnutí, prolamující smysl nejenom $\S 22$ ústavní listiny, ale také $\S 8$ a $\S 13$ zákona o volebním soudu a především převracející podstatu celého sporu, nezůstalo bez široké odezvy.

V rovině politicko-právní se jednalo o interpelaci poslance Charváta a dalších 43 poslanců ze dne 27. června 1923 na vládu ve věci porušení ústavy Volebním soudem. ${ }^{8}$ Uvedení poslanci podrobně upozorňovali na všechny okolnosti případu, skutkové a zejména právní, a namítali porušení ustanovení ústavní listiny o volném mandátu člena Národního shromáždění. Vláda odpověděla dne 25. ř́ijna 1923 velmi stručně a odkázala na to, že soudci Volebního soudu jsou nezávislí, nikdo na ně nemůže uplatňovat žádný vliv, a pokud by tak vláda učinila, jak bylo žádáno v interpelaci, porušila by zákon. ${ }^{9}$

\footnotetext{
7 KOSCHIN, K. Sbirka zásadních rozhodnutí a usnesení volebního soudu. (Zasedání ze ř́jna 1922 až dubna 1925.) III. dil. Praha: Volební soud, 1925, s. 92.

8 Tisk Poslanecké sněmovny č. 4218 v I. volebním období. [online]. Dostupný na: http://psp.cz/eknih/1920ns /ps/tisky/T4218_00.htm. [cit. 25. 08. 2020].

9 Tisk Poslanecké sněmovny č. VI./4251 v I. volebním období. [online]. Dostupný na: http://www.psp.cz /eknih/1920ns/ps/tisky/T4251_00.htm. [cit. 25. 08. 2020].
} 
Rozhodnutí Volebního soudu nezůstalo bez odezvy ani v rovině odborné. Mezi jeho přední kritiky patřili např́íklad J. Hoetzel, tvůrce osnovy ústavní listiny, nebo F. Weyr, přední právní teoretik. J. Hoetzel kladl důraz na rozdíl mezi svobodným vzdáním se mandátu a vzdáním se ho na př́kaz či žádost třetí osoby. ${ }^{10} \mathrm{~F}$. Weyr upozorňoval na obsah $\S 13$ písm. b) zákona o volebním soudu, který byl taxativní a nedával Volebnímu soudu možnost konstatovat ztrátu mandátu z jiného důvodu nad rámec zákona. Podle F. Weyra tedy mohl Volební soud pouze zkoumat, zda důvody pro opuštění strany jsou „nízké a nečestné“, ale nemohl rozhodnout o ztrátě mandátu z důvodů jiných, např́klad uvedených nad rámec zákona v poslaneckém reverzu. ${ }^{11}$

Všichni akademici však rozhodnutí Volebního soudu v př́ípadu poslance Vrbenského a kolegů nekritizovali. Mezi jeho př́znivce patřil B. Baxa, který argumentoval jednak veřejnou mravností, jednak právně. ${ }^{12} \mathrm{Z}$ hlediska morálního B. Baxa upozorňoval ohrožení veřejné mravnosti neplněním a neprosazením př́slibu učiněného poslancem v reverzu. Z hlediska právního uváděl argumenty poukazující na to, že poslanec svůj mandát získává od strany, a nikoliv od voličů. B. Baxa říká výslovně, že v Československu není poslanecký mandát postaven na myšlence zastupitelské, ale je tomu jinak. Uvádí: „U nás volební rád nejen literou, nýbrž i celým duchem svým staví v popředí opět středověký systém mandátní. "13 Odkazuje také na totožný závěr R. Redsloba. ${ }^{14} \mathrm{Z}$ právního hlediska $\mathrm{B}$. Baxa upozorňuje na skutečnost, že zákonodárce sice zavedl vázané kandidátní listiny, ale nedal žádné právní záruky jejich prosazení, což musel svým rozhodnutím učinit až Volební soud. Sice podle B. Baxy rozhodnutím extenzivním, ale právně i morálně správným. ${ }^{15}$

Uvedený názorový spor ukazuje, že koncepce volného parlamentního mandátu nebyla v první československé republice silně přijata. Naopak celých pět let trval spor o povahu mandátu člena parlamentu. Ten byl ovlivněn mimořádně silným postavením politických stran v tehdejším státně-politickém systému. Ve vztahu k parlamentu byla síla politických stran podpořena dále také způsobem ustavení Národního výboru v roce 1918 a z něho odvozeného Národní shromáždění, které nakonec přijalo také definitivní ústavu pro Československo. Členové obou zákonodárných orgánů nebyli voleni, ale vybráni vedeními svých stran, což mělo svůj vliv na vnímání mandátu jako vycházejícího primárně z vůle stran a nikoliv voličů. Svou roli také hrála skutečnost, že přestupy poslanců znamenaly porušení tzv. Švehlova klíče, na jehož základě byl ustaven Národní výbor a posléze Revoluční národní shromáždění jeho rozšířením. ${ }^{16}$

Přes výše popsanou kritiku Volební soud své rozhodnutí v dalších letech potvrdil a vyšel ještě více vstříc pojetí mandátu člena parlamentu coby mandátu imperativního, podléhajícího kontrole z vedení politických stran. Z právního hlediska bylo v tomto směru

10 HOETZEL, J. Správní právo. Část všeobecná. Praha: Melantrich, 1937, s. 478.

11 WEYR, F. Politické strany. In: HÁCHA E. - HOETZEL, J. - WEYR, F. - LAŠTOVKA, K. Slovník veřejného práva československého. Svazek III. Brno: Polygrafia - Rudolf M. Rohrer - Brno, 1934, s. $186-187$.

12 BAXA, op. cit., s. 253-255.

13 Tamtéž, s. 255.

14 REDSLOB, R. Le régime parlementaire. Paris: M. Giard, 1924, s. 270. Odkaz uveden dle: BAXA, op. cit., S. 255.

15 BAXA, op. cit., s. 256.

16 Revoluční národní shromáždění tuto záležitost řešilo v květnu 1919 v případě poslanců Františka Modráčka a Josefa Hudce. 
významné rozhodnutí ve věci ztráty mandátu komunistického poslance M. Kubicska ze dne 17. listopadu 1928. ${ }^{17}$ Návrh Komunistické strany Československa na zbavení mandátu byl v tomto př́padě velmi formální, až lakonický. Strana totiž pouze odkázala na existenci podepsaného poslaneckého reverzu a nevyslyšenou výzvu k rezignaci na mandát, kdy poslanci a senátoři byli vázáni pokyny strany, za kterou kandidovali v parlamentních volbách. Od tohoto rozhodnutí již politické strany ve svých návrzích na zbavení mandátu nemuseli dokládat okolnosti, za kterých se s nimi člen parlamentu rozešel.

Tímto způsobem bylo s mandátem členů parlamentu zacházeno dále po celou první československou republiku a formálně až do přijetí ústavy 9. května v roce 1948.

\section{Pojetí mandátu člena parlamentu v ústavních úpravách z let 1948, 1960 a 1968}

Jestliže ústavní listina z roku 1920 založila mandát členů parlamentu jako volný, přičemž cestou soudních rozhodnutí došlo $\mathrm{k}$ jeho proměně v mandát vázaný, potom další ústavní vývoj pokračoval v linii mandátu vázaného, byt' za poněkud odlišných podmínek. Rozhodujícím okamžikem zde bylo převzetí moci Komunistickou stranou Československa symbolicky spojované s 25. únorem 1948 jako s rozhodujícím dnem v tomto procesu. Zůstaneme-li u určité formální symboliky, potom tento den můžeme považovat za okamžik, kdy došlo k významnému diskontinuitnímu zvratu spočívajícím v opuštění demokratických principů ve prospěch politické hegemonie Komunistické strany Československa, která vedla ke vzniku totalitního politického režimu. Tuto skutečnost musíme nutně brát v potaz také při posuzování charakteru mandátu členů parlamentu.

Zaprvé opuštění principů demokracie a svobody a přebírání moci Komunistickou stranou Československa vedlo v období mezi 25. únorem a 10. březnem ${ }^{18} 1948$ k rezignaci anebo jinému způsobu zastavení výkonu mandátu v př́ípadě desítek poslanců Národního shromáždění. ${ }^{19}$ I když se jednalo o vliv mocenských okolností a nátlaku, a nikoliv o výsledek formálního rozhodování, je nutno tyto př́ípady vnímat jako formu vlivu na výkon mandátu a potlačení jeho volného charakteru.

Zadruhé, a zde již můžeme mluvit z hlediska formálnějšího, nová ústava z 9 . května 1948 nezakotvila mandát poslance Národního shromáždění jako mandát volný. Při její přípravě byla tato záležitost například předmětem odborného vyjádření E. Táborského, který považoval za nepřijatelné, že Volební soud mohl rozhodovat o ztrátě mandátu v jiných př́padech, než při ztrátě volitelnosti člena parlamentu nebo výkonu funkce neslučitelné $\mathrm{s}$ mandátem poslance či senátora. ${ }^{20}$ Nicméně $\mathrm{v}$ textu nové ústavy tyto námitky nebyly zohledněny.

Ústava z 9. května 1948 ve svém § 43 stanoví pouze to, že poslanci vykonávají svůj mandát osobně a mohou se ho kdykoliv vzdát. Otázku charakteru mandátu nechává neřešenou, nicméně výše popsané okolnosti předcházející jejímu schválení ukazují na to, že

\footnotetext{
17 KOSCHIN, K. Sbirka zásadních rozhodnutí a usnesení volebního soudu. (Zasedání z listopadu 1928 až listopadu 1933.) V. Díl. Praha: Volební soud, 1934, s. 134.

18 Dne 10. března 1948 se poprvé po 25. únoru sešlo Národní shromáždění.

19 GRONSKÝ, J. Komentované dokumenty k ústavním dějinám Československa. II. 1945-1960. Praha: Karolinum, 2006, s. 290.

20 TÁBORSKÝ, E. Naše nová ústava. Praha: Čin, 1948, s. 524.
} 
mandát bude fakticky vázaný a podléhat bude vedení Komunistické strany Československa. Další vývoj toto plně potvrdil.

Jeho vyvrcholením bylo schválení tzv. socialistické ústavy, k němuž došlo 11 . července 1960. Tento ústavní dokument na rozdíl od ústavy z 9. května 1948 mimořádně sblížil formální právní úpravu s existující praxí. V záležitosti charakteru mandátu poslance Národního shromáždění byl klíčový čl. 57 ústavy. Ten stanovil, že poslanec je povinen pracovat ve svém volebním obvodu, být ve stálém styku se svými voliči, dbát jejich podnětů a skládat jim účty ze své činnosti. Z uvedeného je patrné, že ústava z roku 1960 zavedla imperativní mandát. Vzorem jí byla ústava SSSR z roku 1936, která ve svém článku 142 stanovila, že člen Nejvyššího sovětu SSSR, stejně jako členové nejvyšších sovětů republik, skládal ze své činnosti účty svým voličům. ${ }^{21}$

S vázaností mandátu se pojí také otázka vyvození odpovědnosti poslance za nedodržení instrukcí. Také s touto věcí právní řád Československa počítal, když ve volebních předpisech zakládal možnost odvolání poslance na veřejných schůzích voličů. ${ }^{22}$ Je však nutno říci, že nikdy nebyl vydán prováděcí předpis, který by stanovil, jakou procedurou mají být zákonem předpokládané veřejné schůze svolány, podle jakých pravidel má probíhat jejich jednání a jak má dojít k odvolání poslance z funkce.

K odvolání poslance z funkce touto cestou došlo, alespoň podle oficiálních zpráv, přinejmenším jednou. A to $\mathrm{v}$ případě zatčeného poslance a ministra vnitra R. Baráka, jak vyplývá ze zprávy předsednictva Národního shromáždění. ${ }^{23}$ Naopak v př́padě poslance generála J. Šejny, ${ }^{24}$ k jehož odvolání mělo dojít na jaře 1968, se př́íslušné veřejné schůze nepodařilo svolat. Veřejnost na Litoměřicku totiž v podmínkách politického uvolnění a vzhledem k rozhořčení z liknavosti a neschopnosti všech zapojených státních orgánů vyjadřovala jednoznačný názor, že tento problém má Národní shromáždění vyřrešit samo. ${ }^{25}$ Předsednictvo Národního shromáždění pod tímto tlakem okolností nakonec došlo k závěru, že není správné nutit voliče k negativnímu volebnímu aktu, a proto případ dne 20. března 1968 vyřešilo zákonným opatřením označovaným jako Lex Šejna, na jehož základě uprchlý poslanec byl zbaven mandátu. ${ }^{26}$

Rok 1968 byl významný také z hlediska pojímání mandátů členů parlamentu. V rámci bouřlivého společenského a politického vývoje v Československu došlo mj. k přijetí velmi rozsáhlé změny ústavy z roku 1960 mající za cíl federalizovat stát a postavit na

21 Text ústavy. [online]. Dostupný na: https://www.departments.bucknell.edu/russian/const/36cons04 .html\#chap11, nebo v originále zde: https://www.prlib.ru/en/node/420920. [cit. 25. 8. 2020].

22 Viz např. ustanovení § 51 zákona č. 37/1960 Sb.

23 Viz stenografický záznam z jednání 12. schůze Národního shromáždění konané dne 23. února 1962. [online]. Dostupný na: http://www.psp.cz/eknih/1960ns/stenprot/012schuz/s012023.htm\#_d. [cit. 25. 08. 2020].

24 Podstata případu generála J. Šejny je čtenáři patrně známa. Proto, a také proto, že není předmětem této práce, okolnosti př́padu nerozepisuji. Nicméně v př́ípadě zájmu je celý př́ípad podrobně popsán v řadě snadno dostupných textů, at' už tištěných anebo internetových. Viz např. MACÁK, M. Dvoji tvář hazardního hráče (Jan Šejna pod drobnohledem VKR). Praha: Ministerstvo obrany ČR - AVIS, 2006. Dostupné také online na: https://adoc.tips/dvoji-tva-hazardniho-hrae.html. [cit. 25. 08. 2020]. Nebo také FELCMAN, O. Československý parlament na prahu Pražského jara. Národní shromáždění na cestě k reformě (1964 - duben 1968) Praha: Nakladatelství Lidové noviny, 2015, s. 149-172.

25 FELCMAN, op. cit., s. 169.

26 Viz stenografický záznam z jednání 20. schůze Národního shromáždění konané dne 29. března 1968. [online]. Dostupný na: http://www.psp.cz/eknih/1964ns/stenprot/020schuz/s020004.htm. [cit. 25. 08. 2020]. 
nový státoprávní základ vztah obou národů Československa. K této změně došlo přijetím ústavního zákona č. 143/1968 Sb. Jeho záběr byl velmi široký, protože podstatně proměnil všechny pasáže dosavadní ústavy upravující postavení nejvyšších ústavních orgánů. Z hlediska podstaty mandátu člena parlamentu bylo rozhodující, že nová ústavní úprava vypustila výslovné ustanovení dřivějšího čl. 57 odst. 1, který počítal s tím, že poslanci mají povinnost skládat účty ze své činnosti svým voličům a dbát jejich podnětů. Ústavní zákon č. 143/1968 Sb. o podstatě mandátu mlčel. Tím z formálně právního hlediska došlo k návratu do stavu platného v rámci ústavy z 9. května 1948.

Z ryze formálně právního hlediska však bylo důležité to, že imperativnost mandátu byla i nadále zakotvena na zákonné úrovni. S možností odvolání poslance voliči na veřejných schůzích počítaly všechny volební zákony v případě, že poslanec zklamal důvěru voličů nebo se dopustil činu nedůstojného funkce poslance, a to jak zákon č. 44/1971 Sb. o volbách do Federálního shromáždění, tak zákon č. 53/1971 Sb. o volbách do České národní $\operatorname{rady.}^{27}$

K závěru, že mandát poslanců je imperativní, dochází také dobová literatura, když konstatuje, že poslanci jsou svým voličům odpovědni a mandát poslance je imperativní. ${ }^{28}$ To ostatně odpovídá povaze soudobého politického režimu. Pokud mohly existovat pochybnosti v období probíhajícího tzv. pražského jara a jeho dozvuků, počátek procesu tzv. normalizace tyto pochybnosti definitivně rozptýlil a potvrdil, že mandát má imperativní charakter.

Zahájení procesu tzv. normalizace s sebou totiž přineslo velmi specifický způsob vyvození odpovědnosti za způsob, kterým členové nejvyšších zastupitelských sborů své mandáty vykonávali. Protože v rámci tzv. normalizace bylo nutno konsolidovat politické poměry mj. také v nejvyšších zastupitelských sborech, kde se řada členů ukázala být pro nové období nespolehlivá a nepoužitelná, bylo nutno vyřešit, jak zejména z Federálního shromáždění a České národní rady tyto osoby odstranit.

Již minulé př́ipady ukázaly, že zákonem zakotvená možnost tzv. negativní volby, tedy odvolání poslanců na veřejných schůzích voličů, není př́liš praktická a nevede ke spolehlivému výsledku. Navíc v podmínkách počínající „,normalizace“ bylo možné pochybovat, zda by veřejnost odvolala z funkcí poslance, kteří byli spojeni s tzv. obrodným procesem během ,pražského jara“. V každém případě by takové veřejné projednávání hrozilo rozjitřením situace místo žádoucí stabilizace. ${ }^{29}$

Proto došlo dne 15. října 1969 k přijetí ústavního zákona č. 117/1969 Sb. o prodloužení volebního období národních výborů, národních rad a Federálního shromáždění, Nejvyššího

27 Oba zákony byly přijaty po nabytí účinnosti ústavního zákona č. 143/1968 Sb. V př́ípadě zákona o volbách do Federálního shromáždění odvolávání poslanců řešilo ustanovení $§ 49$, v případě zákona o volbách do České národní rady se jednalo o ustanovení $§ 48$.

28 Viz komentář A. Pšeničky k čl. 48 ústavního zákona č. 143/1968 Sb. KOLEKTIV AUTORŮ. Československá ústava. Komentář. Praha: Panorama, 1987, s. 310. Shodně P. Peška a S. Zdobinský, viz KOLEKTIV AUTORŮ. Státní právo ČSSR. Praha: Panorama, 1985, s. 184 a s. 212-213.

29 Vyplývá to již z jeho důvodové zprávy, která odkazuje na „současnou vnitropolitickou situaci“ a „,naléhavou potřebu řešit nahromaděné problémy v určitém pořadí“, přičemž oboje znemožňuje provést volby ve stanoveném termínu, tedy do konce roku 1969. Podstata problému spočívala v tom, že vedení Komunistické strany Československa ještě nemělo pod plnou kontrolou situaci ani ve společnosti, ani v zastupitelských sborech. Viz tisk Federálního shromáždění č. 12 z I. volebního období. [online]. Dostupný na: http://www .psp.cz/eknih/1969fs/tisky/t0012_00.htm. [cit. 25. 8. 2020]. 
soudu, krajských, okresních a vojenských soudů. Zásadní ve vztahu k poslancům Federálního shromáždění a národních rad v tomto směru bylo ustanovení jeho $§ 3$ odst. 1-3. Podle něho mohl být poslanec zbaven svého mandátu rozhodnutím zastupitelského sboru, jehož byl členem, a to na návrh př́slušného orgánu Národní fronty. Důvody pro možné zbavení mandátu byly stanoveny celkem tři. Jednalo se o neplnění poslanecké funkce bez vážného důvodu po delší čas, dále narušování politiky Národní fronty činností poslance a posledním důvodem bylo pravomocné odsouzení pro trestný čin.

První důvod měl svůj praktický význam na počátku tzv. normalizace vzhledem k emigraci řady poslanců. Ve vztahu k nezávislému výkonu poslanecké funkce byl zásadním důvod druhý, spočívající v narušování politiky Národní fronty. Jednalo se mimochodem o řešení svou podstatou velmi podobné tomu, které existovalo v předválečném Československu. Pouze rozhodnutí o odvolání poslance z funkce činil vzhledem k proměně politického systému jiný subjekt. Poslanec však byl v obou př́ípadech veden k poslušnosti, a prrípadně postižen ztrátou mandátu z rozhodnutí nadřízeného politického orgánu.

Rozhodujícím kritériem v dané době přirozeně byla činnost poslanců zejména v reformním období roku 1968 a postoj k invazi vojsk Varšavské smlouvy a následnému politickému vývoji. ${ }^{30} \mathrm{~K}$ odvolávání poslanců došlo ve dvou fázích. První, hlavní, proběhla v ř́ijnu 1969. Druhá potom počátkem prosince 1970.

Budeme-li hovořit o hlavní fázi odvolávání, potom samotnému odvolání poslanců předcházely ve smyslu $\S 3$ ústavního zákona č. 117/1969 Sb. pohovory s poslanci, kteří svou činností a postoji nevyhovovali nastolené politické linii. Jak uvádí Z. Jičínský, tyto pohovory v př́ipadě České národní rady probíhaly v říjnu 1969. V průběhu pohovorů bylo $62^{31}$ poslanců vyzváno, aby na své mandáty rezignovali sami s tím, že pokud se tak nestane, budou z funkce na základě výše uvedeného ústavního zákona odvoláni. ${ }^{32}$ Této výzvě se velká většina, konkrétně 53 poslancư ${ }^{33}$ podrobilo, jak je patrné ze zprávy předsedy České národní rady při zahájení její 5. schůze dne 26. listopadu 1969. ${ }^{34}$ Odvolání tedy bylo navrženo $\mathrm{v}$ př́padě devíti poslanců. ${ }^{35} \mathrm{~V}$ případě třech $\mathrm{z}$ nich bylo navrženo odvolání $\mathrm{z}$ důvodů dlouhodobého nevykonávání mandátu bez vážného důvodu podle ustanovení $§ 3$ odst. 1 písm. a) ústavního zákona, v případě zbylých šesti poslanců se jednalo o narušování politiky Národní fronty podle $\S 3$ odst. 1 písm. b) ústavního zákona. Všech devět poslanců bylo z funkce odvoláno. Následně bylo Českou národní radou zvoleno podle návrhu ústředního

30 Podrobné informace o průběhu „normalizace“ České národní rady podává např. Zdeněk Jičínský. Viz JIČÍNSKÝ, Z. Vznik České národní rady v době Pražského jara 1968 a její puisobení do podzimu 1969. Praha: Nakladatelství Svoboda, 1990, s. 122-139.

31 Jak vyplývá ze zprávy předsedy ústředního výboru Národní fronty České socialistické republiky Josefa Korčáka přednesené dne 26. listopadu na 5. schůzi České národní rady. Stenografický záznam. [online]. Dostupný na: http://www.psp.cz/eknih/1969cnr/stenprot/005schuz/s005001.htm. [cit. 25. 8. 2020].

32 JIČÍNSKÝ, op. cit., s. 137.

33 Jejich seznam přednesl předseda České národní rady Čestmír Císař při zahájení její 5. schůze dne 26. listopadu 1969. [online]. Dostupný na: http://www.psp.cz/eknih/1969cnr/stenprot/005schuz/s005001. htm. [cit. 25. 8. 2020].

34 Stenografický záznam. [online]. Dostupný na: http://www.psp.cz/eknih/1969cnr/stenprot/005schuz /s005001.htm. [cit. 25. 8. 2020].

35 Jejich seznam je obsažen v tisku České národní rady č. 47 v I. volebním období. [online]. Dostupný na: http://www.psp.cz/eknih/1969cnr/tisky/t0047_00.htm. [cit. 25. 8. 2020]. 
výboru Národní fronty České socialistické republiky nových 62 poslanců. ${ }^{36}$ Tímto způsobem proběhla obměna téměř jedné třetiny České národní rady a nad tímto zastupitelským orgánem byla získána požadovaná politická kontrola.

Druhá, již menší vlna personální obměny proběhla v České národní radě od září do listopadu 1970. Dělo se tak cestou rezignací poslanců na své mandáty. Celkem se jednalo o devět poslanců. ${ }^{37}$ Později se svých mandátů podle zprávy předsedy České národní rady Evžena Erbana vzdali další čtyři poslanci. ${ }^{38}$ Na uvolněná místa bylo dne 8. prosince 1970 zvoleno Českou národní radou pět nových poslanců. ${ }^{39}$

Odvolávání poslanců se nevyhnulo ani Federálnímu shromáždění. Vzhledem ke způsobu ustavení Federálního shromáždění v přechodném období podle čl. 147 ústavního zákona č. 143/1968 Sb. bylo třeba tuto záležitost řešit pouze ve Sněmovně lidu, nebot' členy Sněmovny národů byli ti poslanci národních rad, kteří původně nebyli členy Národního shromáždění. ${ }^{40}$

Ve Sněmovně lidu proběhlo první odvolání poslanců hned 16. října 1969, tedy v den schválení a současně nabytí účinnosti ústavního zákona č. 117/1969 Sb. Předsedou ústředního výboru Národní fronty České socialistické republiky a současně poslancem Sněmovny lidu Josefem Korčákem bylo navrženo odvolání celkem sedmi poslanců. ${ }^{41}$ Odvolání dvou poslancư ${ }^{42}$ bylo navrženo $\mathrm{z}$ důvodů dlouhodobého nevykonávání mandátu bez vážného důvodu podle ustanovení $§ 3$ odst. 1 písm. a) ústavního zákona. Oba poslanci se zdržovali v zahraničí, kam emigrovali, respektive kde se rozhodli setrvat. V př́padě zbylých pěti poslanců ${ }^{43}$ se jednalo o narušování politiky Národní fronty podle $\S 3$ odst. 1 písm. b) ústav-

36 Jejich seznam je obsažen v tisku České národní rady č. 48 v I. volebním období. [online]. Dostupný na: http://www.psp.cz/eknih/1969cnr/tisky/t0048_00.htm. [cit. 25. 8. 2020].

37 Viz zprávu předsedy České národní rady o činnosti předsednictva ČNR od 9. července do 19. listopadu 1970 obsaženou v tisku České národní rady č. 90 v I. volebním období. [online]. Dostupná na: http://www .psp.cz/eknih/1969cnr/tisky/t0090 00.htm. [cit. 25. 8. 2020].

38 Stenografický záznam. [online]. Dostupný na: http://www.psp.cz/eknih/1969cnr/stenprot/009schuz /s009001.htm. [cit. 25. 8. 2020].

39 Jejich seznam je obsažen v tisku České národní rady č. 94 v I. volebním období. [online]. Dostupný na: http://www.psp.cz/eknih/1969cnr/tisky/t0094_00.htm. [cit. 25. 8. 2020].

40 Tyto záležitosti Sněmovna národů projednala při dvou př́ležitostech, v návaznosti na průběh personální obměny České národní rady. Vzhledem k povaze mandátů vzniklých delegací brala Sněmovna národů pouze na vědomí rozhodnutí učiněná národními radami. V případě prvé fáze personální obměny se jedná o usnesení Sněmovny národů z její 5. schůze konané dne 3. prosince 1969. [online]. Dostupné na: http:// www.psp.cz/eknih/1969fs/sn/stenprot/005schuz/prilohy/priloh01.htm. [cit. 25. 8. 2020]. V př́ípadě druhé fáze personální obměny je to usnesení Sněmovny národů z její 10. schůze konané dne 24. března 1971. [online]. Dostupné na: http://www.psp.cz/eknih/1969fs/sn/stenprot/010schuz/prilohy/priloh02.htm. [cit. 25. 8. 2020].

41 Viz stenografický záznam vystoupení na 5. schůzi Sněmovny lidu konané dne 16. října 1969. [online]. Dostupný na: http://www.psp.cz/eknih/1969fs/sl/stenprot/005schuz/s005001.htm. [cit. 25. 8. 2020].

42 Jednalo se o Jiř́ího Pelikána a Jana Šubrta.

43 Mezi nimi byli všichni čtyři poslanci, kteří dne 16. října 1968 hlasovali v Národním shromáždění proti vyslovení souhlasu s ratifikací „Smlouvy mezi vládou Československé socialistické republiky a vládou Svazu sovětských socialistických republik o podmínkách dočasného pobytu sovětských vojsk na území Československé socialistické republiky“. Tedy Božena Fuková, František Kriegel, Gertruda SekaninováČakrtová a František Vodsloň. Pátým byl generál Václav Prchlík, který se stal nepřijatelným již 15. července 1968 svým veřejným vystoupením kritizujícím strukturu a fungování organizace Varšavské smlouvy, včetně dominance Sovětského svazu, a požadujícím v jejím rámci rovnoprávnější postavení členských států a jejich větší autonomii. 
ního zákona. Všech sedm poslanců bylo z funkce odvoláno. Další dva poslanci Sněmovny lidu byli odvoláni na její 8 . schůzi konané dne 27. května 1970, opět pro nerespektování politiky Národní fronty. Symbolickým vyvrcholením personální rekonstrukce československých zastupitelských sborů bylo zbavení poslaneckého mandátu Alexandra Dubčeka, k němuž došlo na 9. schůzi Sněmovny lidu konané dne 8. července 1970.

Z výše uvedeného je zrretelně patrné, že mandát členů zastupitelských sborů měl v celém období let 1948-1989 vázaný, imperativní charakter. Lišil se pouze způsob, jakým byla odpovědnost za jeho vykonávání vyvozována. Pouze období společenského a politického uvolnění především v roce 1968 tuto skutečnost do značné míry zastřelo, i když jen na krátkou dobu.

\section{Pojetí mandátu člena parlamentu v letech 1989-1990}

Posledním velkým zlomovým mocenským momentem v dějinách Československa byl listopad 1989. Toto období přechodu moci ale také opět přineslo téma převzetí moci a její konsolidace, jak jsme se mohli vidět už dříve v jiných přelomových obdobích politického a ústavního vývoje v Československu. Jeho vyústěním byl ústavní zákon č. 14/1990 Sb. o odvolávání poslanců zastupitelských sborů a volbě nových poslanců národních výborů. Tento ústavní zákon byl jedním z mnoha mocenských nástrojů, pomocí něhož mělo proběhnout převzetí moci, ovšem řízeně, bez skutečně revolučních kroků. Cílem byla v podstatě „legální revoluce“, kdy stávající státní orgány měly být využity k demokratizaci a liberalizaci panujícího systému s vyvrcholením v podobě svobodných voleb. Vše proto, že představitelé Občanského fóra a Verejnosti proti násiliu, tedy organizací zastupujících názor občanů demonstrujících proti stávajícímu systému, se chtěli vyhnout všem střetům, které mohly skončit krveprolitím, a také proto, že tyto organizace nebyly personálně vybaveny $\mathrm{k}$ převzetí všech pozic ve státě.

Jedním z nástrojů, který tuto úlohu mohl pomoci splnit, byl výše zmíněný ústavní zákon č. 14/1990 Sb. ze dne 23. ledna 1990. Jeho základem byl nový mechanismus odvolávání poslanců vedle tehdy stále ještě standardního odvolávání voliči na veřejných schůzích. Tento způsob se opět ukázal jako nevyhovující pro dané období z důvodů nedostatečné praktičnosti. ${ }^{44}$ Proto byl zaveden nový postup a možnost odvolání byla svěřena politické straně, jejímž byl poslanec členem. V případě nestraníků byla pravomoc odvolat svěřena př́íslušnému orgánu Národní fronty, který mohl konat po vzájemné dohodě s Občanským fórem v České socialistické republice a hnutím Verejnost proti násiliu ve Slovenské socialistické republice. Předsednictva komor Federálního shromáždění a národních rad ${ }^{45}$ takové odvolání pouze brala na vědomí.

Ústavní zákon č. 14/1990 Sb. přinesl mechanismus velmi podobný výše popsanému ústavnímu zákonu č. 117/1969 Sb. To vyvolávalo vůči němu nikoliv bezvýznamný odpor, umocněný tím, že svým charakterem šel ústavní zákon proti duchu doby. Aplikace imperativního mandátu měla být cestou ke svobodnému mandátu, odstranění politických

44 Avšak podle ustanovení čl. I odst. 3 ústavního zákona č. 14/1990 Sb. zůstal zachován.

45 V případě národních výborů se jednalo o rady národních výborů, protože ústavní zákon řešil odvolávání také poslanců národních výborů. 
oponentů mělo vést ke svobodné demokracii. Nejednalo se o jediný paradox událostí listopadu 1989 a byl dán právě oním (částečně okolnostmi vynuceným) důrazem na „legální revoluci“.

Příprava a projednávání návrhu ústavního zákona byly mimořádně složité, ${ }^{46}$ doprovázené střety mezi federální vládou a vedením Občanského fóra, a dopadly nakonec tak, že ve Sněmovně lidu návrh schválen byl, ale ve Sněmovně národů, kde se uplatňoval tzv. zákaz majorizace a bylo třeba ústavní většiny dosáhnout jak v české části, tak i ve slovenské, schválen nebyl. Tím došlo k historicky prvému rozporu ve stanoviscích obou sněmoven Federálního shromáždění, a také k prvému rozporu obou národních částí Sněmovny lidu. Jak píše Jiří Suk, tímto okamžikem skončilo období ,jednomyslnosti“. 47 Můžeme dodat, že po mnoha desetiletích.

K odvolávání poslanců obou sněmoven Federálního shromáždění došlo na jejich oddělených schůzích ${ }^{48}$ konaných v obou př́ípadech 30. ledna 1990. V př́ípadě Sněmovny lidu předsedající oznámil, že k danému dni na své mandáty nově rezignovalo 19 poslanců a dalších 19 jich bylo odvoláno podle ústavního zákona č. 14/1990 Sb. Neobsazeno v té chvíli bylo ve Sněmovně lidu celkem 79 mandátů. ${ }^{49}$ Ve Sněmovně národů rezignovalo ke dni 30. ledna 1990 celkem 23 poslanců zvolených v české části federace a 19 poslanců zvolených na Slovensku. Odvoláno bylo 6 poslanců z české části federace a 10 poslanců ze Slovenska. ${ }^{50}$ Neobsazeno v té chvíli bylo ve Sněmovně národů celkem 56 mandátů. ${ }^{51}$

V př́ípadě České národní rady probíhaly rezignace a odvolávání poslanců velmi podobně jako ve Federálním shromáždění. Klíčová rozhodnutí byla přijata na její 20. schůzi konané dne 6. února 1990. K tomuto dni na své funkce rezignovalo 46 poslanců a odvoláno bylo dalších 18 poslanců. Neobsazených tedy bylo celkem 64 mandátů. ${ }^{52}$

Volné mandáty byly v obou zákonodárných sborech obsazeny kooptacemi prováděnými podle ústavního zákona č. 14/1990 Sb. Jejich průběh i důsledky pro Federální shromáždění detailně popisuje P. Roubal. Důsledky nebyly jenom čistě politické, ale také demografické, protože Federální shromáždění se výrazně omladilo, což mělo nejenom vliv z hlediska věku, ale také skutečnosti, že většina stávajících poslanců se narodila až po 2. světové válce. Přirozeně se také výrazně proměnilo politické složení, které již nebylo monolitické, a také složení sociální a profesní. ${ }^{53}$

Mohli bychom shrnout, že aplikace ústavního zákona č. 14/1990 Sb. znamenala pro zákonodárné sbory skutečnou revoluci a převrat. Platí však také jeho již výše uvedené

46 V podrobnostech viz např. SUK, J. Labyrintem revoluce. Aktéři, zápletky a křižovatky jedné politické krize. (Od listopadu 1989 do června 1990) Praha: Prostor, 2003, s. 286-294.

47 Tamtéž, s. 289.

48 V prŕípadě Sněmovny lidu se jednalo o 6. schůzi, v případě Sněmovny národů o 8. schůzi.

49 Viz stenografický záznam z 6. schůze Sněmovny lidu Federálního shromáždění. [online]. Dostupný na: http://www.psp.cz/eknih/1986fs/sl/stenprot/006schuz/s006001.htm. [cit. 25. 8. 2020].

50 Viz stenografický záznam z 8. schůze Sněmovny národů Federálního shromáždění. [online]. Dostupný na: http://www.psp.cz/eknih/1986fs/sn/stenprot/008schuz/s008001.htm. [cit. 25. 8. 2020].

51 Jejich seznam je obsažen v tisku Federálního shromáždění č. 251 v V. volebním období. [online]. Dostupný na: http://www.psp.cz/eknih/1986fs/tisky/t0251_00.htm. [cit. 25. 8. 2020].

52 Viz stenografický záznam z 20. schůze České národní rady. [online]. Dostupný na: http://www.psp.cz /eknih/1986cnr/stenprot/020schuz/s020001.htm. [cit. 25. 8. 2020].

53 Více viz ROUBAL, P. Starý pes, nové kousky. Praha: Ústav pro soudobé dějiny v. v. i., 2013, s. 56 a násl. Dostupné také online: http://forumhistoriae.sk/documents/10180/1433786/kooptace-fulltext.pdf. [cit. 25. 8. 2020]. 
hodnocení, že současně znamenal opětovné vyvození odpovědnosti z předchozí činnosti poslance.

K opuštění principu imperativního mandátu a jeho nahrazení mandátem volným došlo ve dvou fázích. Na ústavní úrovni se tak stalo k 1. dubnu 1990, kdy svou účinnost ztratil ústavní zákon č. 14/1990 Sb. Do budoucna již nemohli být poslanci odvoláváni svými stranami, respektive př́śslušnými orgány Národní fronty. Na zákonné úrovni byl imperativní mandát $\mathrm{v}$ př́ípadě poslanců Federálního shromáždění opuštěn $\mathrm{k}$ 1. březnu 1990, kdy nabyl účinnosti nový zákon o volbách do Federálního shromáždění, publikovaný pod č. 47/1990 Sb. V př́ípadě poslanců České národní rady se tak stalo k 6. březnu 1990, kdy nabyl účinnosti zákon č. 54/1990 Sb. o volbách do České národní rady. Ani jeden z obou zákonů již nepočítal s možností odvolání poslanců jejich voliči na veřejných schůzích ve volebních obvodech. Tím došlo nejenom k posílení nezávislosti postavení poslanců, ale také rozšíření prostoru, v němž bylo vyloučeno vyvozování jejich neodpovědnosti za výkon funkce.

\section{Závěr}

Jak je z výše uvedeného popisu patrné, Československo znalo volný mandát členů parlamentu pouze po dobu zhruba 8 let ze své přibližně 75leté historie. Drtivě převažující byl mandát imperativní, a to bez ohledu na panující režim. Vázaný mandát se prosadil nejprve v podmínkách politicky relativně svobodné a demokratické první republiky. Posléze se stal po válce součástí totalitního politického uspořádání. Opět bez ohledu na panující režim náleželo panství nad mandátem politickým stranám. Rozdíl spočíval převážně v tom, kolik politických stran v systému fungovalo. Je však pravdou, že moc a kontrola komunistické strany po celou dobu její hegemonie nad Československem byla uplatňována důsledněji. To ale bylo dáno samotným charakterem politického systému a jeho totalitními prvky. Rozdíl také spočíval v tom, že zatímco v době první československé republiky byla moc nad mandátem člena parlamentu otevřeně v rukou politických stran, $\mathrm{v}$ době hegemonie Komunistické strany Československa se formálně vše ponechávalo v rukou voličů. Pouze z hlediska panujícího režimu krizové okamžiky odhalily praktickou nepoužitelnost formálně zakotveného mechanismu a nutily režim k hledání jiných řešení, která odhalovala skutečné mechanismy moci.

K obnově volného mandátu došlo v Československu až poté, co došlo k základní konsolidaci nové moci po listopadu 1989. Na ústavní úrovni byl potom volný mandát členů parlamentu zakotven až v ústavě samostatné České republiky. Nynější období 30 let volného mandátu tak vlastně tvoří z hlediska ústavní tradice dosti nesamozrrejmý úsek. A to jak z hlediska formálně právního, tak i z hlediska politické praxe. Protože i když jistě politické strany vybírají své kandidáty do parlamentu důkladně, byli jsme v uplynulých 30 letech svědky řady případů přestupu zejména poslance $\mathrm{z}$ jedné strany do druhé, ale nikdy to nevedlo k soudnímu sporu nebo jinému formálnímu pokusu o zbavení mandátu. Z tohoto hlediska se snaha některých politiků o zakotvení vázanosti mandátu na kandidující stranu zmíněná v úvodu této stati nezdá být vyvolána praktickou potřebou, ale je vedena snad principiálními důvody. 